\title{
INCORPORATING BIODEGRADATION AND ADVANCED OXIDATION PROCESSES IN THE TREATMENT OF SPENT METAL WORKING FLUIDS
}

Jitka Macadam $^{1}$, Haci Ozgencil ${ }^{1}$, Olivier Autin ${ }^{1}$, Marc Pidou ${ }^{2}$, Clive Temple $^{1 *}$, Simon Parsons ${ }^{1}$, Bruce Jefferson $^{1}$

${ }^{1}$ Department of Environmental Science and Technology, Cranfield University, Cranfield, Bedfordshire, MK43 0AL, UK.

${ }^{2}$ Advanced Water Management Centre, University of Queensland, Brisbane, Australia

*Email: c.temple@cranfield.ac.uk. Tel.: +44 1234 754056; fax: +44 1234754036.

\begin{abstract}
The treatment of spent metalworking fluids (MWFs) is difficult due to their complex and variable composition. Small businesses often struggle to meet increasingly stringent legislation and rising costs as they need to treat this wastewater on site annually over a short period. Larger businesses that treat their wastewater continuously can benefit from the use of biological processes, although new MWFs designed to resist biological activity represent a challenge. A three-stage treatment is generally applied with the oil phase being removed first followed by a reduction in COD loading with polishing of the effluent's quality in the final stage. The performance of advanced oxidation processes (AOPs), which could be of benefit to both types of businesses was studied. After assessing the biodegradability of spent MFW, different AOPs were used $\left(\mathrm{UV} / \mathrm{H}_{2} \mathrm{O}_{2}\right.$, photo-Fenton and $\left.\mathrm{UV} / \mathrm{TiO}_{2}\right)$ to establish the treatability of this wastewater by hydroxyl radicals $(\mathrm{OH})$. The interactions of both chemical and biological treatments were also investigated. The wastewater was found to be readily biodegradable in the Zahn-Wellens test with $69 \%$ $\mathrm{COD}$ and $74 \%$ DOC removal. $\mathrm{UV} / \mathrm{TiO}_{2}$ reactor was found to be the cheapest option achieving a very good COD removal (82\% at 20 min retention time and $10 \mathrm{~L} \cdot \mathrm{min}^{-1}$ aeration rate). Photo-Fenton was found
\end{abstract}


to be efficient in terms of degradation rate, achieving $84 \%$ COD removal $\left(1 \mathrm{M} \mathrm{Fe}^{2+}, 40 \mathrm{M} \mathrm{H}_{2} \mathrm{O}_{2}, 20.7 \mathrm{~J}^{-\mathrm{cm}^{-}}\right.$

$\left.{ }^{2}, \mathrm{pH} 3\right)$ and also improving the wastewater's biodegradability, followed by $\mathrm{UV} / \mathrm{H}_{2} \mathrm{O}_{2}\left(40 \mathrm{M} \mathrm{H}_{2} \mathrm{O}_{2}, 34.5\right.$ $\mathrm{J} . \mathrm{cm}^{-2}, \mathrm{pH}$ 9). UV/ $\mathrm{H}_{2} \mathrm{O}_{2}$ process was the most effective in removing recalcitrant COD post-biological treatment stage.

Keywords: biodegradation, $\mathrm{H}_{2} \mathrm{O}_{2}$, photocatalysis, photo-Fenton, UV

\section{Introduction}

Metalworking fluids (MWFs) are widely used in manufacturing industries for the lubrication and cooling of metal tools within machining processes. MWFs remove small metal chips, reduce the friction between work pieces, optimise tool life, provide protection against corrosion and improve the finished quality of the manufactured products [1]. Worldwide over $2,000,000 \mathrm{~m}^{3}$ is used annually although the wastewater volume could be ten times higher due to the dilution of the MWFs prior to use. In the UK industry alone, over $400,000 \mathrm{~m}^{3}$ of spent MWFs are produced annually with the disposal costs estimated to range between $£ 8$ and $£ 16$ million per year [2]. The average disposal cost per $1 \mathrm{~m}^{3}$ of spent MWFs is $£ 20$ - $£ 40$, however this cost will be significantly higher for smaller businesses ( $£ 40$ - $£ 80)$.

There are two main categories of MWFs; oil based (straight oils and soluble oils) and water based (synthetic and semi-synthetic fluids) with a single product containing up to 60 different components and more than 300 different substances known to be used in MWFs [3]. In Europe, the tightening legislation regarding the waste disposal (European Union Water Directive, 2000/60/EC) and the waste from incineration (European Union Directive, 2000/76/EC) has lead manufacturing industries to consider treating their wastes on-site prior to disposal. The development and growing use of water soluble MWFs with enhanced cooling characteristics has resulted in difficulties during the wastewater treatment leading to increased process complexity and costs. Conventional chemical and physical methods are most commonly used during the treatment of spent MWFs and depending on the level of treatment required; one, two or three stages are generally applied [4]. Solids and the oil phase are removed during the primary 
stage with the secondary stage being used to reduce the volume and COD loading. Further, tertiary treatment is often required to polish the effluent quality in order to meet the increasingly stringent limits.

New emphasis has been put into developing and enhancing the biological treatment option with promising results [5]. Although previous studies suggested that 10-15\% of COD in spent MFWs is aerobically non-biodegradable and this is even higher for anaerobic systems, recently, COD removals reaching 96 and 97\% were reported [6,7]. Variable effluent quality and the use of new, enhanced and biocide containing products represent a challenge for biological treatment but the main disadvantage is the need to operate these systems on a continuous basis which makes them unsuitable for smaller businesses. There is a strong need to develop an effective system which could be used by smaller companies on an on/off basis as well as improve the biological treatment efficiency for larger businesses.

Both of these challenges could be addressed by the introduction of advanced oxidation processes (AOPs) into the treatment flow sheet. AOPs have the potential to remove recalcitrant and toxic compounds and improve the biodegradability of the wastewater due to the generation of non-selective and highly oxidising $\mathrm{OH}$ radicals. The processes of concern here include indirect photolysis $\left(\mathrm{UV} / \mathrm{H}_{2} \mathrm{O}_{2}\right)$, photoFenton (UV/ $/ \mathrm{Fe}^{2+} / \mathrm{H}_{2} \mathrm{O}_{2}$ ) and heterogeneous photocatalysis $\left(\mathrm{UV} / \mathrm{TiO}_{2}\right)$ and involve a number of different OH forming mechanisms. During $\mathrm{UV} / \mathrm{H}_{2} \mathrm{O}_{2}$, the radicals are mainly produced by $\mathrm{H}_{2} \mathrm{O}_{2}$ photolysis. By adding $\mathrm{Fe}^{2+}$ into the system, the production can be enhanced through the formation of photoactive $\left[\mathrm{Fe}(\mathrm{OH})^{2+}\right]$ complex [8]. Different mechanism plays a role in the UV/TiO 2 system where the photoactivation of $\mathrm{TiO}_{2}$ leads to a generation of electron $\left(\mathrm{e}^{-}\right)-$hole $\left(\mathrm{h}^{+}\right)$pairs which subsequently interact with water and dissolved $\mathrm{O}_{2}$ to produce $\mathrm{OH}$ as well as other radicals $\left(\mathrm{OH}_{2}, \mathrm{O}_{2}\right)$ [9]. Organics adsorbed on $\mathrm{TiO}_{2}$ can also directly react with the generated $\mathrm{h}^{+}$. AOPs have been previously applied for the treatment of industrial wastewaters and wastewaters containing highly toxic and recalcitrant compounds $[10,11,12]$. They have also been reported to significantly enhance the biodegradability of recalcitrant compounds such pesticides and pharmaceuticals as well as remove the recalcitrant organics post- 
biological stage $[8,13]$. Further, $\mathrm{UV} / \mathrm{TiO}_{2}$ proved to be a very economical and effective method in treating biological effluent of dying wastewater [14]. However the treatment of high organic load and complex waste such as spent MWFs has not been widely reported to the best of our knowledge.

\section{Aims and scope}

The scope of this study was to investigate the applicability of UV based AOPs $\left(\mathrm{UV} / \mathrm{H}_{2} \mathrm{O}_{2}\right.$, photo-Fenton and $\mathrm{UV} / \mathrm{TiO}_{2}$ ) in the treatment of $\mathrm{MWF}$ wastewater. This study was conducted with the main aim of developing low chemical treatment solution for smaller businesses which can be operated on an ON-OFF basis. A potential of using AOPs to enhance the biodegradation of spent MWFs was also addressed.

A semi-synthetic MWF was pre-treated using ultrafiltration (UF) to remove the emulsified oil and the biodegradability of the resulting effluent was studied. The potential of direct photolysis, $\mathrm{UV} / \mathrm{H}_{2} \mathrm{O}_{2}$, $\mathrm{UV} / \mathrm{Fe}^{2+} / \mathrm{H}_{2} \mathrm{O}_{2}$ and particularly $\mathrm{UV} / \mathrm{TiO}_{2}$ process to treat the UF permeate was investigated with the possibility of combining biodegradation and AOPs to enhance the final effluent quality.

\section{Materials and Methods}

\subsection{Reagents and solutions}

The wastewater used in this study was the UF permeate of a semi-synthetic spent MWF obtained from a machining facility in the UK. The principal characteristics of the wastewater were as follows: COD 14055 mg.L $\mathrm{L}^{-1}$, BOD $5460 \mathrm{mg} . \mathrm{L}^{-1}$ (non-seeded) and $5880 \mathrm{mg} . \mathrm{L}^{-1}$ (seeded), TOC $4600 \mathrm{mg} . \mathrm{L}^{-1}$, TN 1690 mg. $\mathrm{L}^{-1}$, TP $<0.5 \mathrm{mg} . \mathrm{L}^{-1}$, alkalinity (as $\mathrm{CaCO}_{3}$ ) $3480 \mathrm{mg} . \mathrm{L}^{-1}$, conductivity $4.78 \mathrm{mS} . \mathrm{cm}^{-1}$ and $\mathrm{pH}$ 9. Unless otherwise stated, the spent MWF was diluted to a COD of $1000 \mathrm{mg} \cdot \mathrm{L}^{-1}$ with deionised water prior use. For AOP experiments, hydrogen peroxide $\left(\mathrm{H}_{2} \mathrm{O}_{2}\right)$ was analytical grade and purchased as a stabilised $35 \%$ (wt.) solution from Fisher Scientific UK Ltd. (Loughborough, UK). Ferrous sulphate heptahydrate, $\mathrm{FeSO}_{4}$ . $7 \mathrm{H}_{2} \mathrm{O}$ (EA West, Grimsby, UK) was used in the photo-Fenton experiments. Titanium dioxide (Aeroxide ${ }^{\circledR} \mathrm{TiO}_{2} \mathrm{P} 25$ ) with a specific surface area of $50 \pm 15 \mathrm{~m}^{2} \cdot \mathrm{g}^{-1}$, anatase to rutile ratio of 80:20 with 
an average primary particle size of $21 \mathrm{~nm}$ was purchased from Lawrence Industries (Tamworth, UK). For $\mathrm{pH}$ adjustments, $0.5 \mathrm{M}$ sulphuric acid $\left(\mathrm{H}_{2} \mathrm{SO}_{4}\right)$ and $1 \mathrm{M}$ sodium hydroxide $(\mathrm{NaOH})$, both purchased from Fisher Scientific UK Ltd. (Loughborough, UK) were used. The manganese oxide $\left(\mathrm{MnO}_{2}\right)$ powder, used for removing the residuals of peroxide, was laboratory reagent grade and purchased from VWR (Lutterworth, UK). All the chemicals used to prepare the mineral solution for the biodegradation test (OECD, 1992) were of analytical grade and purchased from Fisher Scientific UK Ltd. (Loughborough, UK).

\subsection{Biological degradation of the spent $M W F$}

The biodegradability of the MWF was assessed with the standardised Zahn-Wellens/EMPA test no. 302B [15] in 5L cylindrical glass reactors and kept in the dark. Solutions were aerated and mixed with compressed air diffused through a porous air sparger and were saturated with dissolved oxygen ( 9 mg.L $\mathrm{L}^{-}$

$\left.{ }^{1}\right)$. The inoculum was obtained from a pilot plant treating sewage at Cranfield University. A concentration of $1 \mathrm{~g} . \mathrm{L}^{-1}$ dry matter was used in all the reactors. Diethylene glycol with an initial COD of $1010 \mathrm{mg} . \mathrm{L}^{-1}$ was used as the reference compound for monitoring the activity of the sludge. The MWF was tested at two initial CODs, 412 and $988 \mathrm{mg} . \mathrm{L}^{-1}$. All the blanks, controls and test samples were run in duplicate to ensure reproducibility of results. The solutions $\mathrm{pH}$ values were monitored daily and held between 7 and 7.5 to ensure optimum conditions. $60 \mathrm{ml}$ of each sample were filtered through glass micro fiber filter of pore size $1.3 \mu \mathrm{m}$ prior the analysis. Degradation percentage $\left(D_{t}\right)$ was calculated using equation $D_{t}=\left[1-\left(C_{t}-C_{B}\right) /\left(C_{A}-C_{B A}\right)\right] \times 100$ where $C_{t}$ and $C_{A}$ represent the COD of the test sample at a time $\mathrm{t}$ and at $3 \mathrm{~h}$ respectively; $\mathrm{C}_{\mathrm{B}}$ and $\mathrm{C}_{\mathrm{BA}}$ represent the $\mathrm{COD}$ in the blank at a time $\mathrm{t}$ and at $3 \mathrm{~h}$ respectively.

\subsection{Photochemical degradation of the spent $M W F$}

\subsubsection{Collimated beam apparatus}

A Wedeco AG bench scale collimated beam (CB) apparatus (Herford, Germany) fitted with four 30W monochromatic low pressure mercury lamps (emitting at $254 \mathrm{~nm}$ ) was used for UV-C irradiation. $250 \mathrm{ml}$ of test solutions was placed in a Petri dish at $22 \mathrm{~cm}$ from the light source and stirred with a magnetic 
stirrer. UV irradiance was determined to be $19.2 \mathrm{~W} \cdot \mathrm{m}^{-2}$ by uridine actinometry [16]. The lamps were allowed to warm up for 10 min to ensure consistent light output before irradiating the test solutions.

\subsubsection{Photocatalytic reactor}

An annular, plug flow, single path reactor which operates in continuous mode (Water Innovate, Cranfield, UK) of following dimensions; $d_{i}=52 \mathrm{~mm}$ and $1=270 \mathrm{~mm}$ was equipped with a medium pressure lamp (0.6 kW; Hanovia, Slough, UK) housed in a quartz sleeve. The distance between the external surface of the sleeve and the internal wall of the reactor was $2.5 \mathrm{~mm}$. The spent MWF was mixed with $\mathrm{TiO}_{2}$ in a 201 container and the resulting slurry was pumped into the vertically positioned reactor at its base with aeration achieved through a diffuser situated underneath the reactor inlet. There was no recirculation and the treated effluent was collected and filtered $(1.2 \mu \mathrm{m})$ prior to analysis. The reactor was equipped with a cooling jacket in order to avoid overheating.

\subsubsection{Experimental Procedures}

Initial AOP experiments were conducted in the $\mathrm{CB}$ apparatus. For the $\mathrm{UV} / \mathrm{H}_{2} \mathrm{O}_{2}$ experiments, peroxide was added to the test MWF solutions at different initial concentrations $\left(1,4\right.$ and 8 g. $\left.\mathrm{L}^{-1}\right)$ as based on Schuch et al. (2000) and $\mathrm{pH}$ was adjusted prior to UV irradiation. For the photo-Fenton experiments, ferrous sulphate from a stock solution $\left(68.08\right.$ g. $\mathrm{L}^{-1}$ of $\mathrm{FeSO}_{4} \cdot 7 \mathrm{H}_{2} \mathrm{O}, \mathrm{pH}$ adjusted to 1.5 to avoid any precipitation) was added straight after $\mathrm{H}_{2} \mathrm{O}_{2}$. Initial $\mathrm{pH}$ was then adjusted to 3. To compare photo-Fenton with $\mathrm{UV} / \mathrm{H}_{2} \mathrm{O}_{2}$, ferrous ions were added at a concentration of 0.165 g. $\mathrm{L}^{-1}$ in order to achieve $\mathrm{Fe}^{2+}: \mathrm{H}_{2} \mathrm{O}_{2}$ molar ratio of 1:10 and 1:40 at $\mathrm{H}_{2} \mathrm{O}_{2}$ concentrations of 1 and 4 g. $\mathrm{L}^{-1}$ respectively. In the case of $\mathrm{UV} / \mathrm{TiO}_{2}$ experiments, $\mathrm{pH}$ was adjusted after $\mathrm{TiO}_{2}$ addition and irradiation was started after dark adsorption equilibrium was reached. Preliminary dark adsorption tests were conducted to identify the optimum $\mathrm{TiO}_{2}$ dose (0.5-15 g. $\left.\mathrm{l}^{-1}\right)$ as well as the adsorption equilibrium period (0-24h). The effluent (initial COD of 988

mg. $\mathrm{L}^{-1}$ ) from the biodegradation study was centrifuged, filtered and then stored in a cold room. Thereafter, optimised AOPs were applied to further reduce the COD of the biodegraded effluent. In all AOP experiments, fresh test solutions were prepared before irradiation under each UV dose investigated. 
After irradiation, solutions containing any solids $\left(\mathrm{TiO}_{2}\right.$ or iron precipitates) were filtered prior to analysis. Those containing residuals of $\mathrm{H}_{2} \mathrm{O}_{2}$, which is known to interfere with COD measurements, were treated with $\mathrm{MnO}_{2}$ powder and then filtered [10].

Further $\mathrm{UV} / \mathrm{TiO}_{2}$ experiments were carried out in the photocatalytic reactor at a flow rate of $8.5,17,34$, 170 and $340 \mathrm{ml} \mathrm{min}{ }^{-1}$ resulting in a retention time of 20,10, 5, 1 and 0.5 minutes respectively. A range of air flow rates $\left(0-201 \mathrm{~min}^{-1}\right)$ was tested to insure sufficient mixing of the treated solution inside the reactor chamber. The first effluent sample was collected after at least one retention time had passed from the start of the experiment and further 2 samples were collected at one minute intervals.

\subsection{Analysis}

The dissolved organic carbon (DOC) was determined with a Shimadzu 5000A analyser (Shimadzu, Milton Keynes, UK). COD measurements were performed using Spectroquant@ cell test kits purchased from VWR (Lutterworth, UK) with a NOVA 60 spectrophotometer (Merck, Nottingham, UK). Carbonaceous BOD was measured on seeded and non-seeded samples (spent MWF only) according to the blue book standard methods [17]. Final effluent from Cranfield University sewage works was used as the seed to provide additional source of microorganisms. Residual $\mathrm{H}_{2} \mathrm{O}_{2}$ was determined qualitatively with colorimetric Merckoquant® peroxide test strips purchased from VWR (Lutterworth, UK).

\subsection{Cost analysis}

Power consumption has been assessed using modified Electrical Energy per Order $\left(\mathrm{E}_{\mathrm{EO}}\right)$ based on a relationship (Equation 1) developed by Bolton, where $\mathrm{P}$ is the rated power in $\mathrm{kW}$, $\mathrm{t}$ is the irradiation time in $\min , \mathrm{V}$ is the volume of water treated in litres, $\mathrm{C}_{\mathrm{inf}}=$ the influent and $\mathrm{C}_{\mathrm{eff}}=$ the effluent COD concentration in $\mathrm{mg} \mathrm{l}^{-1}[18]$. Although based on a $90 \%$ removal, where this was not achieved, the maximum removal values obtained here were used. The cost of chemicals added was as follows: $\mathrm{H}_{2} \mathrm{O}_{2}$ (35\%) $£ 270$ per ton, $\mathrm{FeSO}_{4}, 7 \mathrm{H}_{2} \mathrm{O} £ 70$ per ton [10], $\mathrm{H}_{2} \mathrm{SO}_{4}(98 \%) £ 55$ per ton and electricity $£ 0.04$ $\mathrm{k} / \mathrm{Wh}$. Cost of $\mathrm{TiO}_{2}$ addition was not considered since the catalyst can be reused. 


$$
\mathrm{E}_{\mathrm{EO}}\left(\mathrm{kWh} \mathrm{m}^{-3}\right)=\frac{\mathrm{P} \times \mathrm{t} \times 1000}{V \times 60 \times \log \left(\frac{\mathrm{C}_{\text {inf }}}{\mathrm{C}_{\text {eff }}}\right)}
$$

\section{Results}

\subsection{Biological degradation of spent metalworking fluids}

The biodegradation of spent MWF was investigated at two different initial concentrations (CODi $=412$ and $988 \mathrm{mg} \cdot \mathrm{L}^{-1}$ ) and in both cases the COD began to decrease from the start of the experiment with over $50 \%$ removed after 4 days leading to $68-69 \%$ removal after 20 days (Figure 1). This indicates that the microbial population has reached the maximum rate at the lower concentration. In both cases, just over $30 \%$ of the initial COD remained in the treated solution. The $\mathrm{BOD}_{5} / \mathrm{COD}$ data indicate that the initial biodegradability of the MWF $\left(\mathrm{BOD}_{5} / \mathrm{COD} \sim 0.35\right)$ was higher than the biodegradability of the reference compound; hence the faster COD decrease for the MWF. The reference compound, diethylene glycol showed very low biodegradation rate during the first few days corresponding to an initial $\mathrm{BOD}_{5} / \mathrm{COD}$ ratio of 0.02 which increased to 0.21 after 6 days leading to an increase in COD removal which was then completed within 11 days. In terms of DOC, $50 \%$ were biodegraded in both MWF samples within four days with a maximum removal observed after 11 days of $74 \%$ and $66 \%$ for the higher and lower strength solutions respectively. Overall, the level of biodegradation achieved here indicates biocompatibility of this wastewater [15]. 


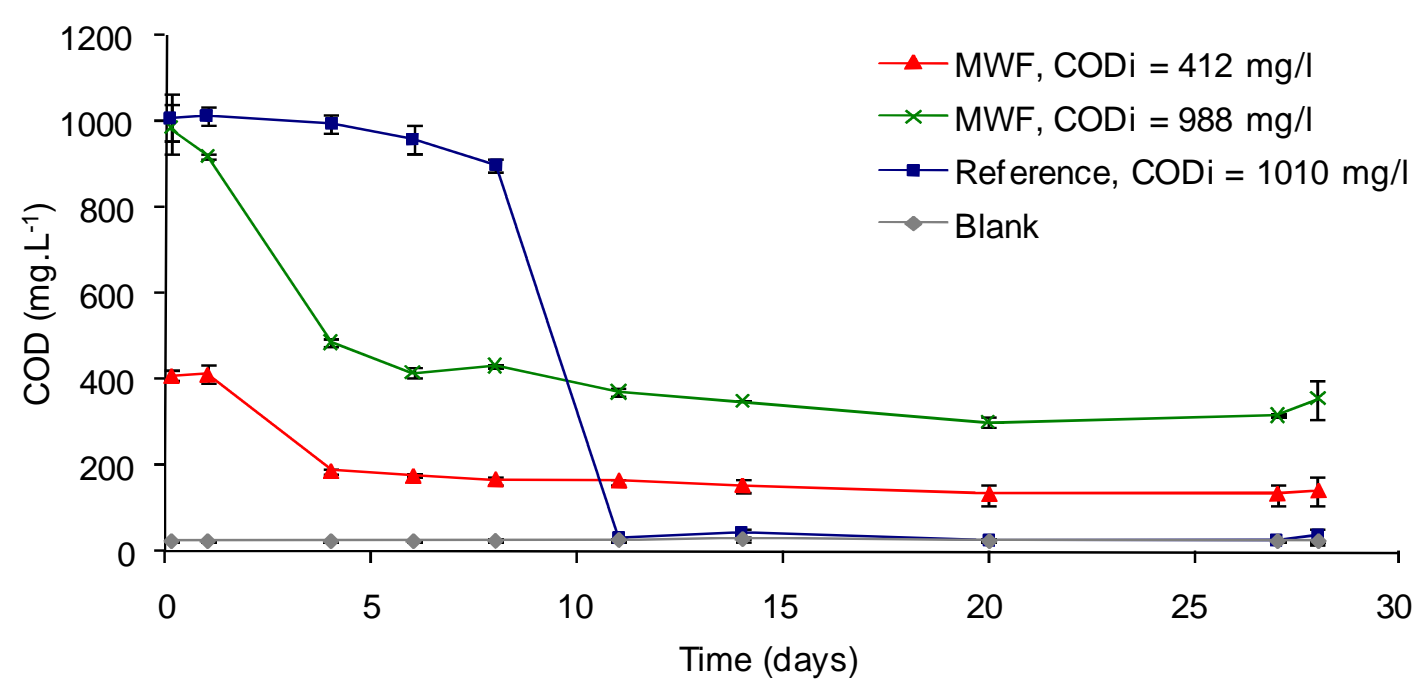

Figure 1. COD removal versus time in the Zahn-Wellens tests.

The results from other studies investigating the biodegradation of spent MWFs vary depending on the origin and type of the wastewater and the treatment conditions but generally, under optimised conditions high COD removals can be achieved. Most of these studies looked at aerobic degradation of various simulated (freshly mixed MWFs) or spent MFWs. To illustrate, Hilal et al. [5] obtained over 90\% COD removal in optimised aerobic reactor with specifically developed bacterial consortium, Anderson et al. [6] achieved over $96 \%$ COD reduction during a treatment of simulated semi-synthetic MWF in an membrane biological reactor (MBR) and Cheng et al. [7] achieved 97\% removal during thermophilic aerobic treatment of spent MWF at $50^{\circ} \mathrm{C}$. Largely, this type of waste is suitable for biological treatment however, as mentioned previously such treatment does not represent solution for smaller businesses.

\subsection{Treatment of spent MWF with AOPs}

Treatment of spent MWFs with direct photolysis depends on the presence of UV absorbing organics. The molar absorbance coefficient of MWF sample (with a COD of $100 \mathrm{mg} . \mathrm{L}^{-1}$ ) was measured at $41.91 . \mathrm{cm}^{-1}$ at $254 \mathrm{~nm}$ (wavelength used for the UV treatment in this study). However, photolysis did not reduce COD or TOC (results not shown) for UV doses of up to $34.5 \mathrm{~J} . \mathrm{cm}^{-2}$ (corresponding to $5 \mathrm{~h}$ irradiation). 
Control experiments with 4 g.l ${ }^{-1}$ of $\mathrm{H}_{2} \mathrm{O}_{2}$ in the absence of irradiation showed that no degradation occurred in the dark (Figure 2a). At the maximum UV dose studied here, $34.5{\mathrm{~J} . \mathrm{cm}^{-2}}^{2}$ and initial $\mathrm{H}_{2} \mathrm{O}_{2}$ concentration of $4 \mathrm{~g} . \mathrm{l}^{-1}$, the COD removal was $89 \%$ with $\sim 1 \mathrm{~g} . \mathrm{l}^{-1}$ of residual $\mathrm{H}_{2} \mathrm{O}_{2}$ in solution indicating that higher UV dose could have further increased COD removal. Reducing initial $\mathrm{H}_{2} \mathrm{O}_{2}$ concentration to $1 \mathrm{~g} . \mathrm{l}^{-1}$ lowered the COD removal at $34.5 \mathrm{~J} . \mathrm{cm}^{-2}$ to only $65 \%$. No additional benefit was observed when the initial $\mathrm{H}_{2} \mathrm{O}_{2}$ concentration was increased to $8 \mathrm{~g} \cdot \mathrm{l}^{-1}$ achieving COD removal of $85 \%$ at $34.5 \mathrm{~J} . \mathrm{cm}^{-2}$. It is known that $\mathrm{H}_{2} \mathrm{O}_{2}$ can potentially act as a scavenger of ${ }^{\circ} \mathrm{OH}$ radicals if present in sufficient amounts [19]. Lowering the $\mathrm{pH}$ from 9 to 5 also proved to be counter-productive and a significantly reduced COD removal of $71 \%$ was achieved at pH 5 with a UV dose of $34.5 \mathrm{~J} . \mathrm{cm}^{-2}$ and 4 g. ${ }^{-1}$ of $\mathrm{H}_{2} \mathrm{O}_{2}$.

A $\mathrm{pH}$ of 3 was selected for the Fenton's reagent (FR) studies since it is widely known that Fenton processes have better efficiencies in acid conditions [20]. Control experiments with only $\mathrm{Fe}^{2+}$ (coagulation) or $\mathrm{Fe}^{2+} / \mathrm{H}_{2} \mathrm{O}_{2}$ (dark Fenton) showed poor degradation (Figure 2b) but the combination of $\mathrm{Fe}^{2+} / \mathrm{H}_{2} \mathrm{O}_{2}$ at molar ratio of 1:40 and UV $\left(0.165\right.$ g.L $\mathrm{L}^{-1} \mathrm{Fe}, 4 \mathrm{~g} . \mathrm{L}^{-1} \mathrm{H}_{2} \mathrm{O}_{2}$ and $\left.20.7 \mathrm{~J} . \mathrm{cm}^{-2}\right)$ gave a maximum

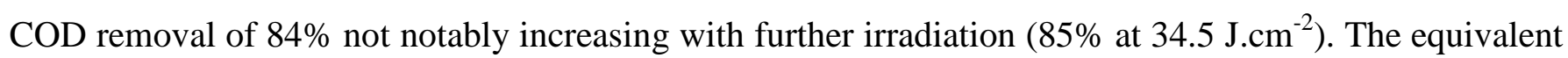
TOC removals were 75 and $76 \%$ respectively. The initial degradation rate under these conditions was faster than for $\mathrm{UV} / \mathrm{H}_{2} \mathrm{O}_{2}\left(4 \mathrm{~g} . \mathrm{L}^{-1}, \mathrm{pH}\right.$ 9) with pseudo-first order initial rate constant of $0.62 \mathrm{~h}^{-1}$ and over $50 \%$ of both COD and TOC removed in less than 1 hour of UV irradiation $\left(6.9 \mathrm{~J} . \mathrm{cm}^{-2}\right)$. In comparison, double the UV dose was required to achieve the same removal with $\mathrm{UV} / \mathrm{H}_{2} \mathrm{O}_{2}$ with the initial rate constant of $0.34 \mathrm{~h}^{-1} . \mathrm{Fe}^{2+}: \mathrm{H}_{2} \mathrm{O}_{2}$ molar ratio of 1:10 (0.165 g.L $\left.\mathrm{L}^{-1} \mathrm{Fe}, 1 \mathrm{~g} \cdot \mathrm{L}^{-1} \mathrm{H}_{2} \mathrm{O}_{2}\right)$ did achieve poorer removals reaching a plateau at $52 \%$ of COD removed $\left(13.8 \mathrm{~J} . \mathrm{cm}^{-2}\right)$. Higher UV dose did not increase removal significantly (56\% at $\left.34.5 \mathrm{~J} . \mathrm{cm}^{-2}\right)$ and the final TOC removal at this UV dose was also much lower (45\%) in comparison to the higher $\mathrm{H}_{2} \mathrm{O}_{2}$ concentration.

$\mathrm{UV} / \mathrm{TiO}_{2}$ process is effectively a 'chemical free' way of generating 'OH radicals as the $\mathrm{TiO}_{2}$ catalyst can be recycled and therefore offers an effective alternative to the above investigated processes. In order to 
identify the optimum treatment conditions, the effect of lowering the $\mathrm{pH}$ was again investigated with the treatment studied at $\mathrm{pH} 9$ and $\mathrm{pH}$ 5. Initial dark adsorption tests conducted at $\mathrm{pH} 9$ and initial COD of $1052 \mathrm{mg} . \mathrm{L}^{-1}$ identified $10 \mathrm{~g} . \mathrm{l}^{-1}$ as the optimum $\mathrm{TiO}_{2}$ dose and 10 minutes as sufficient adsorption period but desorption was observed over longer periods. At pH 5 and 10 g. $l^{-1}$ of $\mathrm{TiO}_{2}$, dark adsorption equilibrium was reached within $30 \mathrm{~min}$. At an initial COD concentration of $1050 \mathrm{mg} . \mathrm{L}^{-1}$ removal of $34 \%$

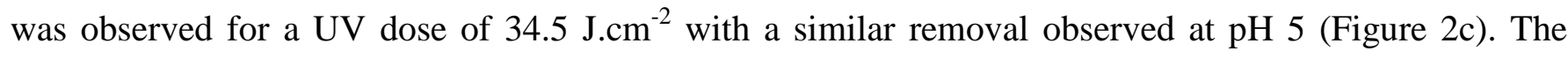
initial zero order rate constant was $64.6 \mathrm{mg} \cdot \mathrm{l}^{-1} \cdot \mathrm{h}^{-1}$. It has been reported previously that the $\mathrm{UV} / \mathrm{TiO}_{2}$ process is rather limited at high COD concentrations as a high organic load will saturate the $\mathrm{TiO}_{2}$ surface as well as reduce the photonic efficiency leading to photocatalyst deactivation [21]. Therefore the effect of lowering the initial concentration of the MFW was studied here and by reducing the initial COD concentration to $589 \mathrm{mg} . \mathrm{L}^{-1}$, the final removal increased to $66 \%$ at the maximum dose studied $\left(34.5 \mathrm{~J} . \mathrm{cm}^{-}\right.$ ${ }^{2}$ ). This is a significant improvement, however in comparison to the other AOPs studied here even at half the COD loading; the removal achieved is still much lower. 
(a)

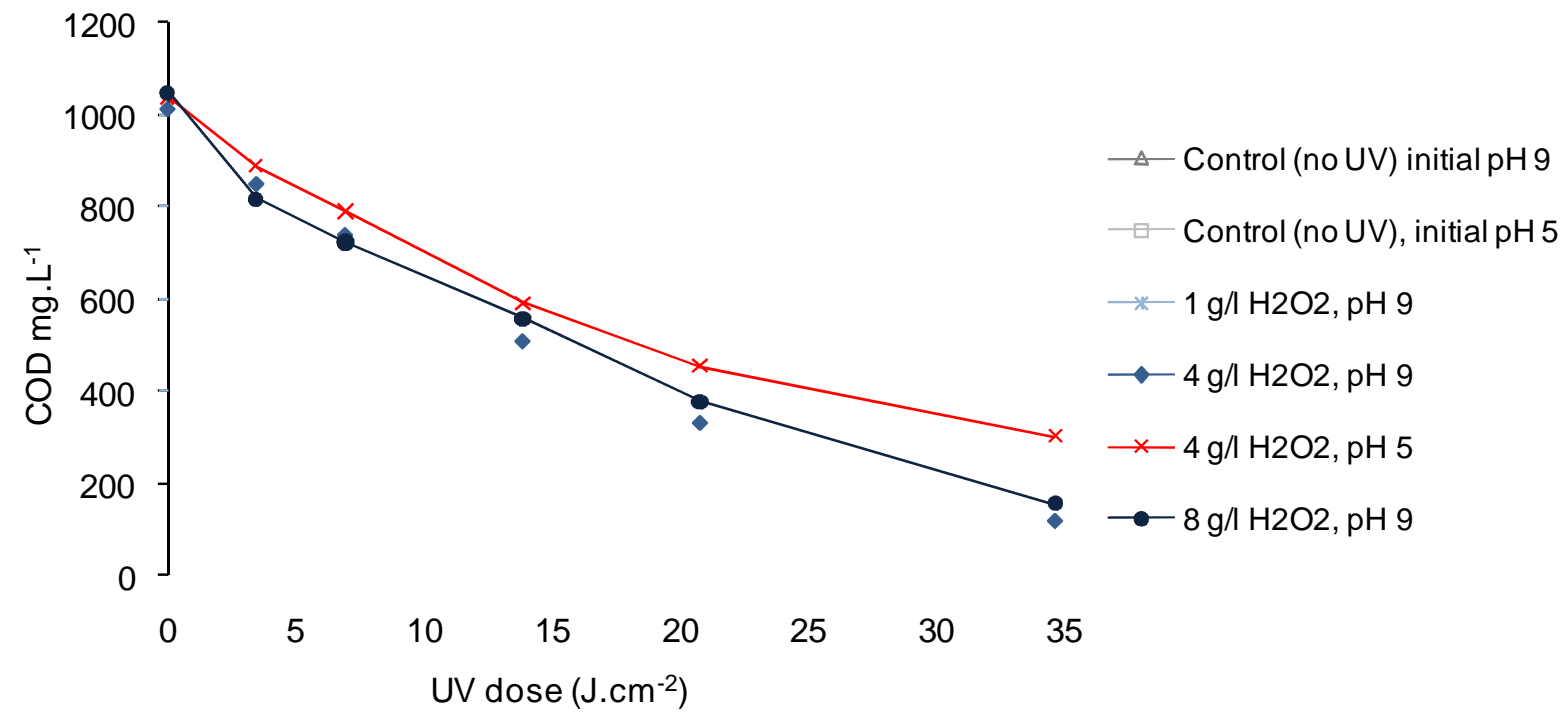

(b)

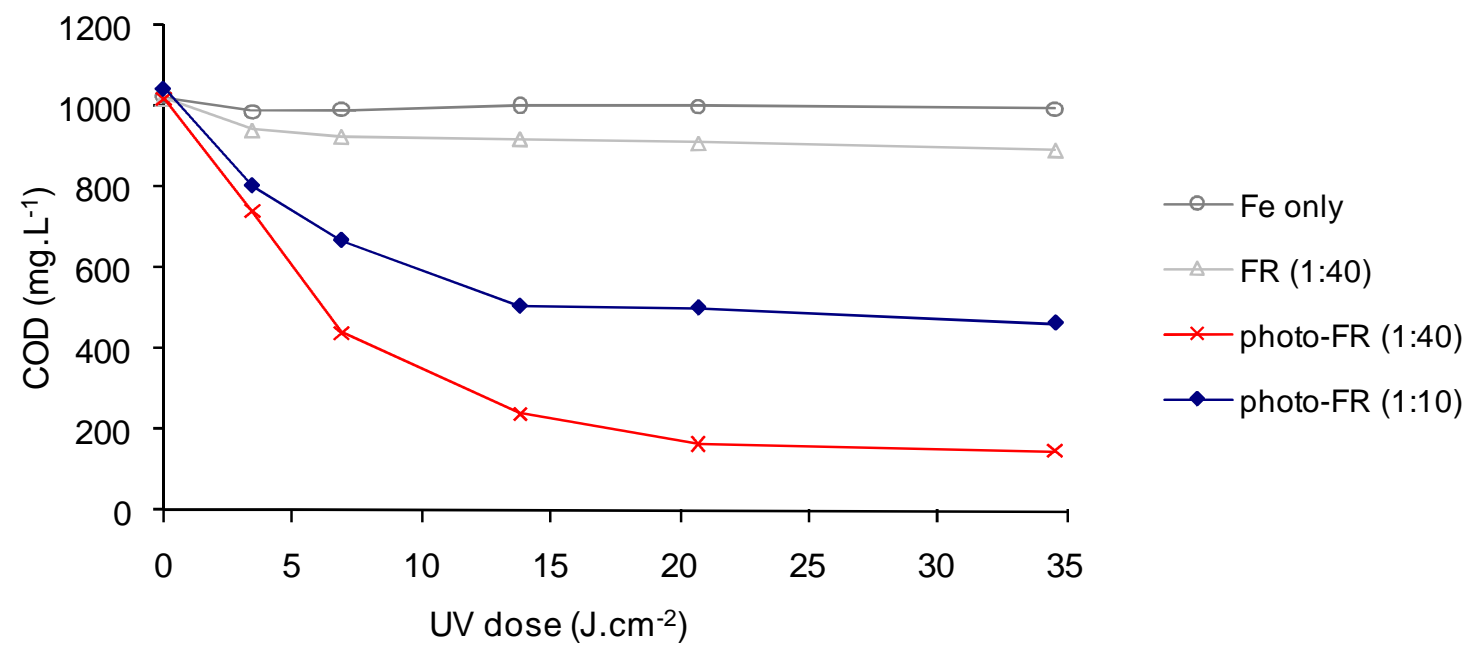

(c)

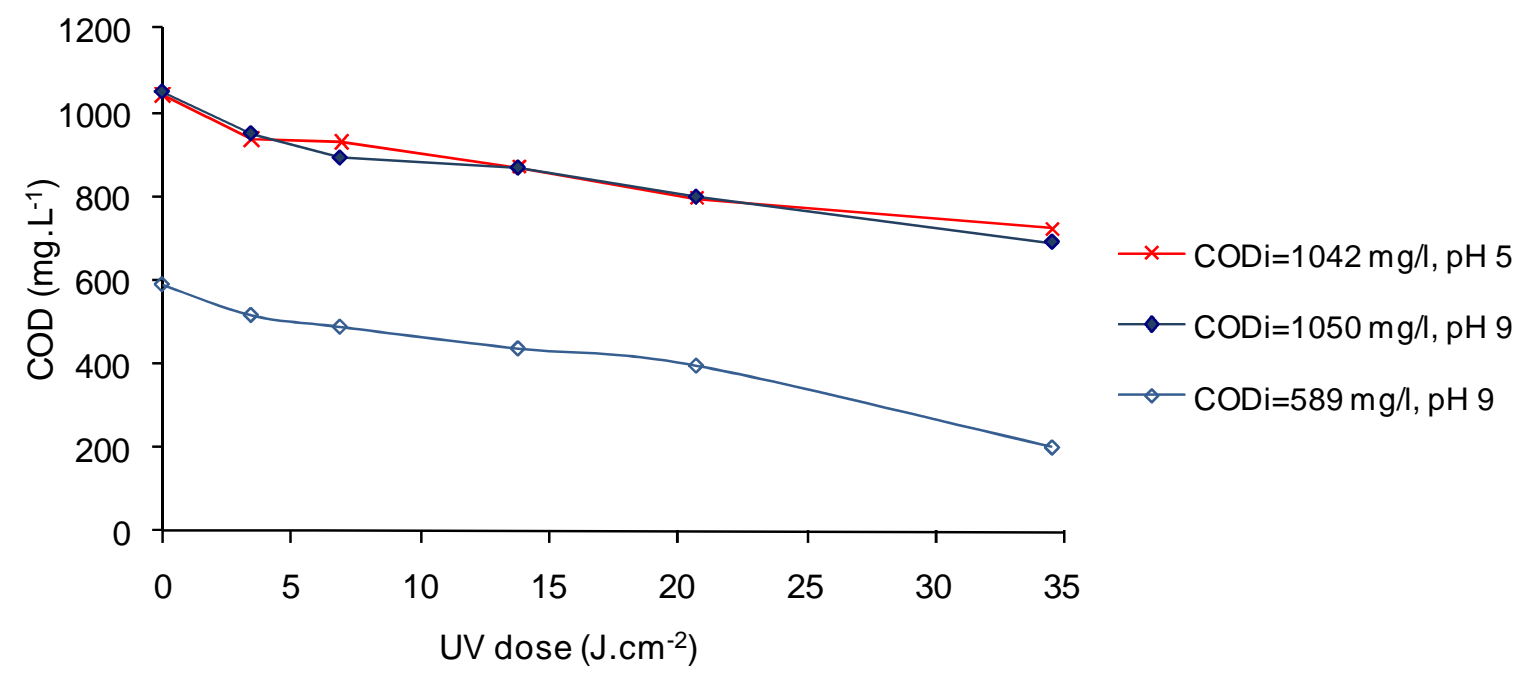

Figure 2. COD removal with (a) $\mathrm{UV} / \mathrm{H}_{2} \mathrm{O}_{2}$, (b) photo- Fenton and (c) $\mathrm{UV} / \mathrm{TiO}_{2}\left(10 \mathrm{~g} . \mathrm{L}^{-1}\right)$ in the $\mathrm{CB}$ apparatus under different experimental conditions. 
As mentioned previously, CB apparatus was used to conduct all UV utilising experiments in order to control the UV dose delivered throughout this study. However, this system appeared to have limitations when used for the photocatalysis. Despite mixing, it was not always possible to avoid the settlement of $\mathrm{TiO}_{2}$ particles in the periphery of the container, inevitably leading to poor activation of the catalyst. Additional experiments were conducted using a photocatalytic reactor to increase the catalyst activation an promising results have been obtained with the COD removal increasing with longer retention time and higher aeration rate (Figure 3). Apart for enhancing the catalyst mixing the aeration also leads to the formation of a superoxide radical which further increases the process efficiency. The maximum removal of $82 \%$ was observed at a retention time of 20 minutes and an aeration rate of 20 L.min ${ }^{-1}$. There is an indication in the literature that this process can be applied in more challenging conditions and it was reported being used in the treatment of industrial wastewater [22]. Further, Muruganandham and Swaminathan [23] reported a complete decolourisation of a reactive yellow azo dye by $\mathrm{UV} / \mathrm{TiO}_{2}\left(4 \mathrm{~g} . \mathrm{L}^{-1}\right)$ after 60 minute-treatment in photo-reactor equipped with eight $8 \mathrm{~W}$ medium pressure UV lamps set in parallel and emitting $365 \mathrm{~nm}$ of peak wavelength.

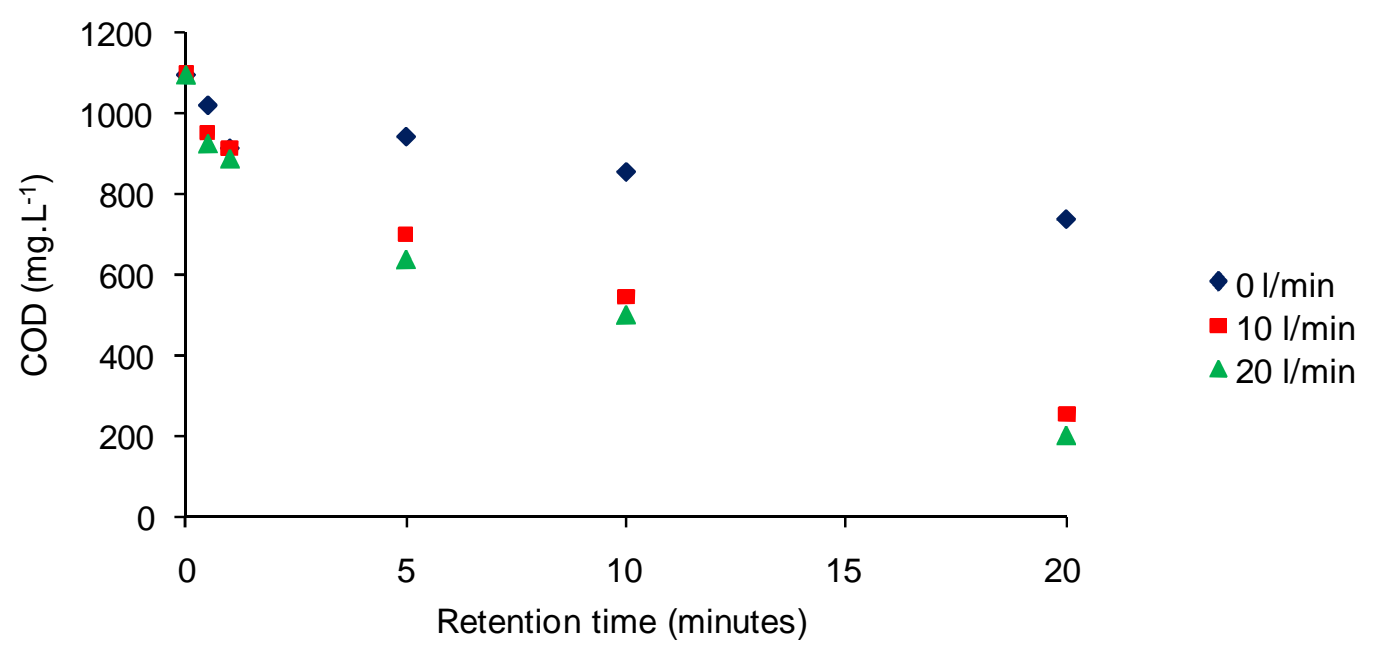

Figure 3. The effect of various retention time and different mixing conditions on COD removal in the photocatalytic reactor; retention time of 20 minutes is equivalent to $0.2 \mathrm{kWh}$. 
To put the use of AOPs into a context here is quite hard as the literature on the treatment of spent metalworking fluids by these processes is very limited. Generally, it is assumed that high organic load wastewater will be too expensive to treat by any AOP due to the amount of chemicals or energy needed to achieve significant removals. Miller and Anderson [24] reported only 19\% COD removal during $\mathrm{UV} / \mathrm{H}_{2} \mathrm{O}_{2}$ treatment of MWF wastewater of similar organic strength $\left(\mathrm{COD}=1390 \mathrm{mg} . \mathrm{L}^{-1}\right)$. However, others investigating the treatment of high organic load industrial wastewater reported much more promising results. For illustration, Azbar et al. [10] obtained 85\% COD reduction for a dye effluent with a COD of $930 \mathrm{mg} . \mathrm{L}^{-1}$ in 90 minutes with $\mathrm{UV} / \mathrm{H}_{2} \mathrm{O}_{2}$ process where the peroxide concentration was 300 mg. $\mathrm{L}^{-1}$. Comparing these to the current results, it is clear that the semi-synthetic spent MWF is treatable by $\mathrm{OH}$ radicals produced during the $\mathrm{UV} / \mathrm{H}_{2} \mathrm{O}_{2}$ process, although significant levels of energy are required to achieve this. Number of studies used the photo-Fenton process to degrade wastewaters containing highly toxic organic compounds. Galvão et al. [25] achieved 99\% mineralisation in wastewater contaminated with diesel at $\mathrm{Fe}^{2+}: \mathrm{H}_{2} \mathrm{O}_{2}$ molar ratio of 1:500. They also found a similar trend when comparing photo-Fenton with $\mathrm{UV} / \mathrm{H}_{2} \mathrm{O}_{2}$ with the photo-Fenton being much faster at reducing the organic content. Here, initial first order rate constants $\left(0.62 \mathrm{~h}^{-1}\right.$ for photo-Fenton and $0.34 \mathrm{~h}^{-1}$ for $\left.\mathrm{UV} / \mathrm{H}_{2} \mathrm{O}_{2}\right)$ at the optimum conditions highlight faster degradation rates for photo-Fenton but with a similar maximum COD removal achieved (85\% in comparison with $89 \%$ for $\mathrm{UV} / \mathrm{H}_{2} \mathrm{O}_{2}$ ) although at a much lower UV dose. For photo-Fenton a plateau was reached after UV doses of 13.8 and $20.7{\mathrm{~J} . \mathrm{cm}^{-2}}^{-2}$ for ratios of 1:10 and 1:40 respectively. These plateaux corresponded to the depletion of $\mathrm{H}_{2} \mathrm{O}_{2}$ from the solutions. Although the removal was similar for $\mathrm{UV} / \mathrm{H}_{2} \mathrm{O}_{2}$ and photo-Fenton processes, the latter has a clear advantage in the lower energy requirement. However, the chemicals required to lower the $\mathrm{pH}$ during the photo-Fenton process and to adjust it back afterwards should be considered. The main advantage of the $\mathrm{UV} / \mathrm{TiO}_{2}$ process is that no chemicals are required and it was previously found to be very effective in removing colour and COD from high organic load wastewater [14]. Although not very successful here in removing COD during the $\mathrm{CB}$ trials, high removals were achieved in the photocatalytic reactor, although at much higher power input $(0.6 \mathrm{~kW})$. 
The effectiveness of an AOP to remove the organics depends on the rate of $\mathrm{OH}$ formation and the availability of $\mathrm{OH}$ to react with the target organic compound [26]. Under the conditions used in this study, lower amounts of $\mathrm{OH}$ were likely to be produced during the $\mathrm{UV} / \mathrm{H}_{2} \mathrm{O}_{2}$ treatment than during the photo-Fenton process. In $\mathrm{UV} / \mathrm{H}_{2} \mathrm{O}_{2}$ system at $\mathrm{pH} 9$, the production of ${ }^{\circ} \mathrm{OH}$ radicals by $\mathrm{H}_{2} \mathrm{O}_{2}$ photolysis is reduced as $\mathrm{H}_{2} \mathrm{O}_{2}$ also undergoes decomposition to $\mathrm{H}_{2} \mathrm{O}$ and $\mathrm{O}_{2}$. Further, $\mathrm{HO}_{2}{ }^{-}$anion formed under these conditions scavenges both, $\mathrm{OH}$ and $\mathrm{H}_{2} \mathrm{O}_{2}$ [27]. In $\mathrm{UV} / \mathrm{Fe}^{2+} / \mathrm{H}_{2} \mathrm{O}_{2}$ system, additionally to the above mentioned photolysis, $\mathrm{Fe}^{2+}$ ion forms under acidic conditions the most photoactive ferric iron - water complex, $\left[\mathrm{Fe}\left(\mathrm{OH}_{2}\right)^{2+}\right]$ leading to a significant and fast production of $\mathrm{OH}$ radicals [8]. In $\mathrm{UV} / \mathrm{TiO}_{2}$ system, apart for radicals $\left(\mathrm{OH}, \mathrm{OH}_{2}, \mathrm{O}_{2}\right)$ produced by the interaction of $\mathrm{e}^{-}-\mathrm{h}^{+}$pairs with dissolved water and $\mathrm{O}_{2}$, organic pollutants adsorbed on the $\mathrm{TiO}_{2}$ can also directly react with $\mathrm{h}^{+}$. However, if the photons are unable to reach the $\mathrm{TiO}_{2}$ particles, neither $\mathrm{h}^{+}$nor $\mathrm{OH}$ can be formed leading to poor treatment efficiency.

\subsection{The potential of combining AOPs with biological degradation of spent MWFs}

The effect of AOP treatment on the biodegradability of MWFs was studied by monitoring the change in the $\mathrm{BOD}_{5} / \mathrm{COD}$ ratio of samples through the AOP treatment. BOD measurements of both seeded and nonseeded samples were unaffected by the UV irradiation and seeded samples depicted a constant $\mathrm{BOD}_{5} / \mathrm{COD}$ ratio of 0.42 compared to 0.31 for non-seeded ones. Only the results from the seeded samples are further reported. The effects of the three AOPs $\left(\mathrm{UV} / \mathrm{H}_{2} \mathrm{O}_{2}\right.$, photo-Fenton and, $\left.\mathrm{UV} / \mathrm{TiO}_{2}\right)$, at their previously determined optimum conditions, on the $\mathrm{BOD}_{5} / \mathrm{COD}$ ratio of the treated $\mathrm{MWF}$ samples are summarised in Figure 4. 


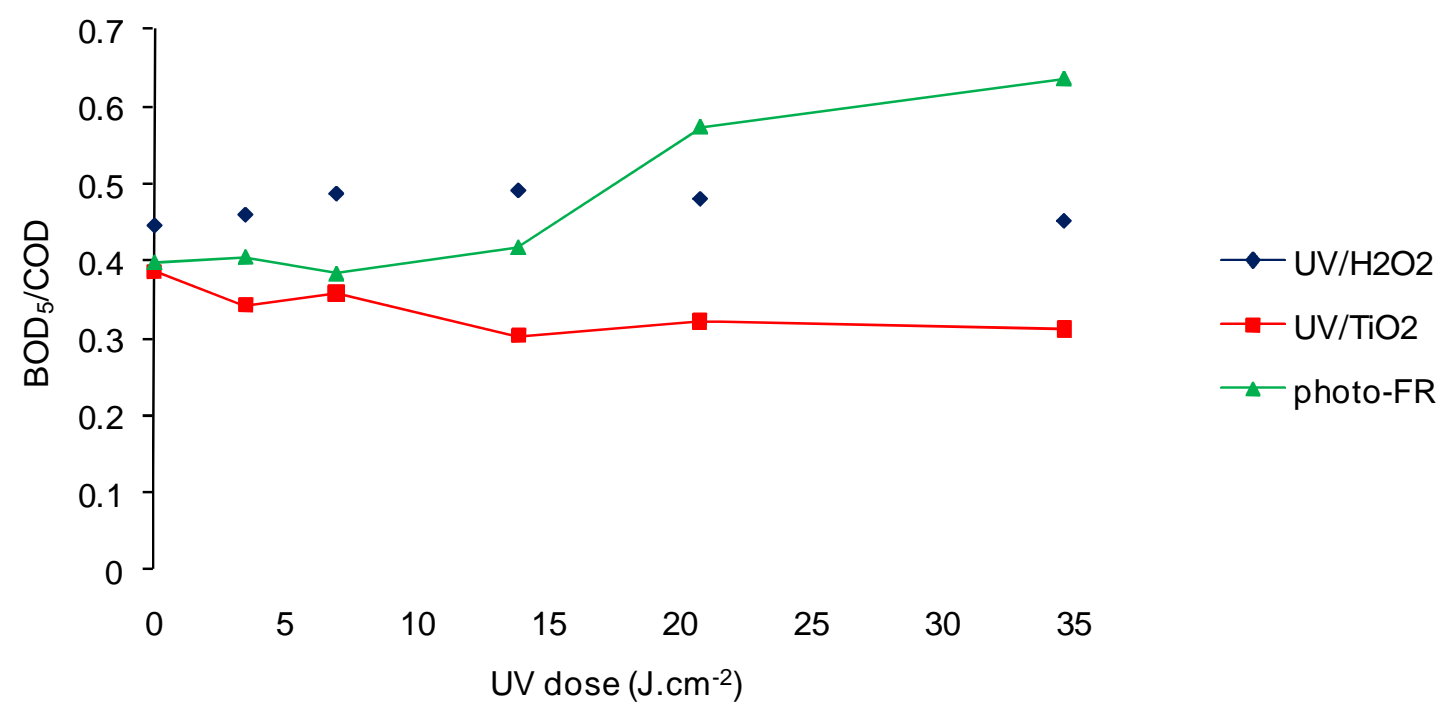

Figure 4. Evolution of biodegradability with applied UV dose $(\mathrm{CB})$ during the AOP treatments: $U V / \mathrm{H}_{2} \mathrm{O}_{2}$ (4 g.L ${ }^{-1}, \mathrm{pH}$ 9), UV/TiO 2 (10 g.L $\mathrm{L}^{-1}, \mathrm{pH}$ 9) and photo-Fenton (0.165 g.L $\mathrm{L}^{-1} \mathrm{Fe}, 4$ g.L $\mathrm{L}^{-1} \mathrm{H}_{2} \mathrm{O}_{2}$ and pH 3); seeded samples.

The $\mathrm{UV} / \mathrm{H}_{2} \mathrm{O}_{2}$ and $\mathrm{UV} / \mathrm{TiO}_{2}$ processes did not extend the biodegradability of $\mathrm{MWF}$. UV/TiO ${ }_{2}$ treatment actually decreased the $\mathrm{BOD}_{5} / \mathrm{COD}$ ratio of the wastewater from 0.39 to 0.30 after applying a UV dose of $13.8 \mathrm{~J} . \mathrm{cm}^{-2}$ but no further change was recorded at higher UV doses. These results are in agreement with those of [28] who reported that a cottonseed wastewater pre-treated with $\mathrm{UV} / \mathrm{TiO}_{2}$ showed only $55 \%$ biological COD removal in comparison to $95 \%$ for the non-treated effluent. The biodegradability of the MWF marginally increased during the $\mathrm{UV} / \mathrm{H}_{2} \mathrm{O}_{2}$ process from 0.44 to 0.49 at a UV dose of $6.9 \mathrm{~J} . \mathrm{cm}^{-2}$ but

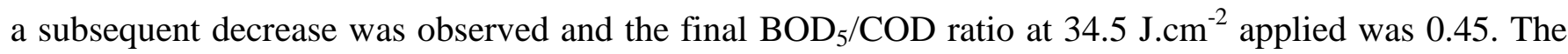
only substantial increase of the biodegradability of the MWF wastewater was observed during the photo-

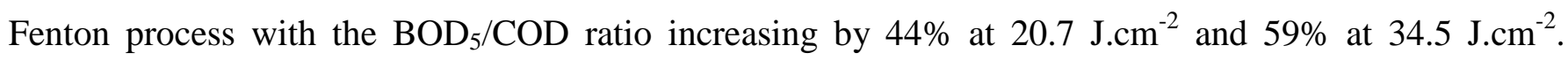
Although this increase is significant, it would come at a very high price as the energy required to achieve it is also substantial. Photo-Fenton was previously reported in the literature to enhance the biodegradability of non-biodegradable organic compounds present in industrial effluents [8].

The other option is to remove the compounds resistant to biodegradation after the biological stage and apply the $\mathrm{AOP}$ as a fine polishing step. Here, $\mathrm{UV} / \mathrm{H}_{2} \mathrm{O}_{2}$, photo-Fenton and $\mathrm{UV} / \mathrm{TiO}_{2}$ (at the optimal 
treatment conditions determined previously) were applied to 'polish' the biodegraded effluent from the Zahn-Wellens test (Figure 5).

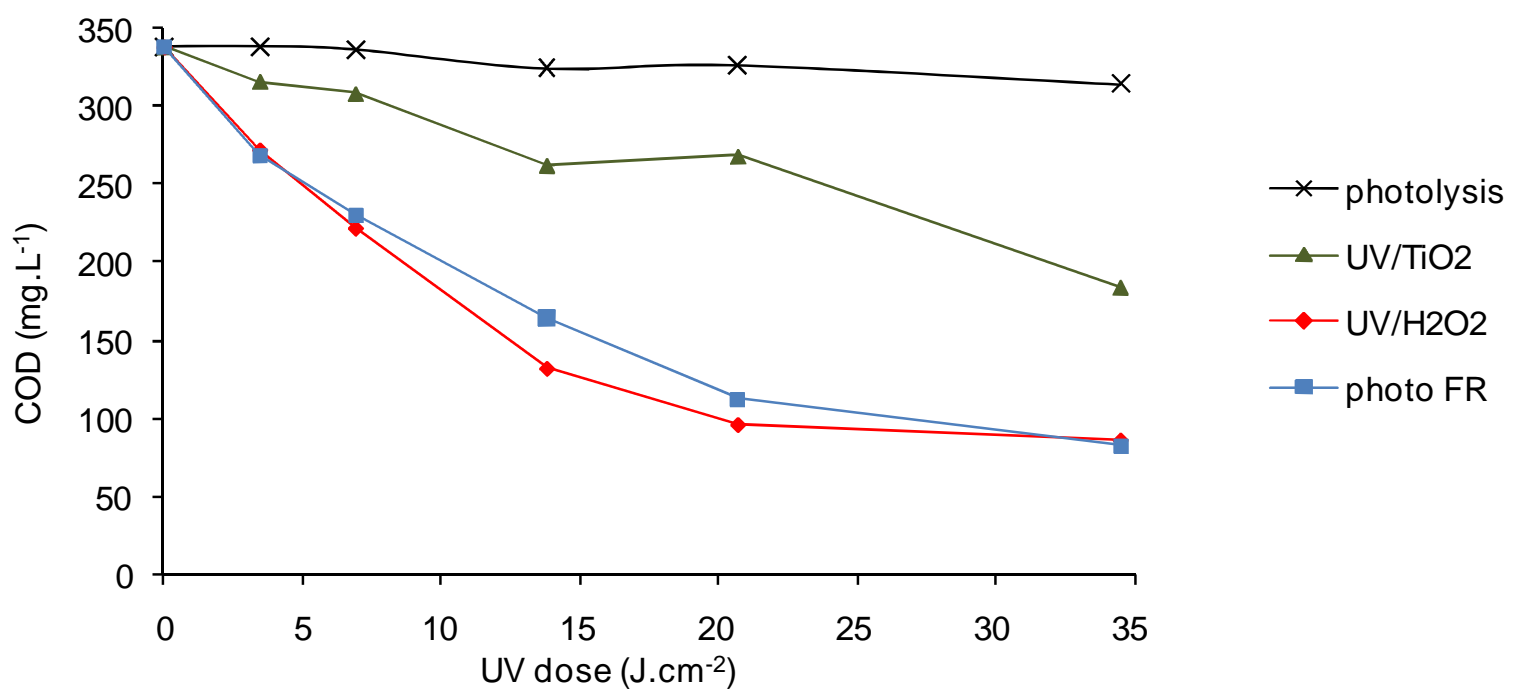

Figure 5. The removal of bio-recalcitrant COD by an AOP: UV/ $\mathrm{H}_{2} \mathrm{O}_{2}\left(4 \mathrm{~g} . \mathrm{L}^{-1}, \mathrm{pH}\right.$ 9), UV/TiO $2\left(10\right.$ g.L $\mathrm{L}^{-1}$, pH 9) and photo-Fenton (0.165 g.L. $\mathrm{L}^{-1} \mathrm{Fe}, 4$ g.L $\mathrm{L}^{-1} \mathrm{H}_{2} \mathrm{O}_{2}$ and $\left.\mathrm{pH} 3\right)$ using the $\mathrm{CB}$ apparatus.

Direct photolysis was unable to treat the bio-recalcitrant COD and showed only marginal COD or TOC removal, $7 \%$ and $6 \%$ respectively. During the $\mathrm{UV} / \mathrm{TiO}_{2}$ treatment, the residual COD decreased by $46 \%$ at the higher UV dose applied with the TOC removal only 25\%. Photo-Fenton and $\mathrm{UV} / \mathrm{H}_{2} \mathrm{O}_{2}$ proved to be equally effective to treat the biodegraded effluent. Both processes reduced the COD from $338 \mathrm{mg} . \mathrm{L}^{-1}$ by approximately $70 \%$ at a $\mathrm{UV}$ dose of $20 \mathrm{~J} . \mathrm{cm}^{-2}$. However, there was still $\sim 1$ g.L. $\mathrm{L}^{-1}$ of $\mathrm{H}_{2} \mathrm{O}_{2}$ remaining at this stage but no further improvement in removal was observed when a higher UV dose was applied. At 34.5

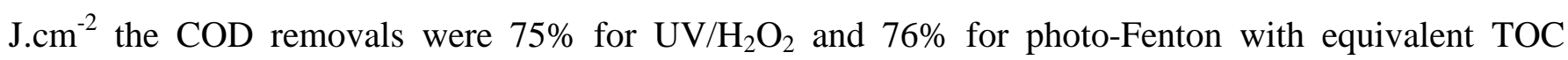
removals of $68 \%$ and $66 \%$ respectively. This indicates that the remaining $\sim 100 \mathrm{mg} . \mathrm{L}^{-1}$ of COD was highly recalcitrant. The photo-Fenton and $\mathrm{TiO}_{2}$ exhibited lower initial rate constants for the biodegraded effluent $\left(0.36 \mathrm{~h}^{-1}\right.$ and $29.0 \mathrm{mg} \cdot \mathrm{l}^{-1} \cdot \mathrm{h}^{-1}$ respectively), whereas the rate constant of $\mathrm{UV} / \mathrm{H}_{2} \mathrm{O}_{2}\left(0.43 \mathrm{~h}^{-1}\right)$ increased when compared to the constants obtained for the non-treated wastewater. However the UV dose 
required for removing $72 \%$ of the recalcitrant COD was still very high $\left(20.7 \mathrm{~J} . \mathrm{cm}^{-2}\right)$ rendering this approach very expensive.

\section{Technology comparison}

The presented treatability results highlighted the capability of utilising ${ }^{\circ} \mathrm{OH}$ for the treatment of MWF either as the main treatment process or as a polishing process post pre-treatment in a biological reactor. The common feature across all the options is the use of UV lamps to generate the $\mathrm{OH}$ radicals and so further comparison was undertaken in terms of energy utilisation and costs associated with the different options based on the optimum conditions established in the treatability tests (Table 1).

Table 1: The options for treatment of metalworking wastewater ranked based on the treatment efficiency and energy and chemical costs (biological treatment and sludge disposal were not included). The AOPs considered were at the following conditions: UV/ $\mathrm{H}_{2} \mathrm{O}_{2}\left(4\right.$ g.L $\left.\mathrm{L}^{-1}, \mathrm{pH} 9\right), \mathrm{UV} / \mathrm{Fe}^{2+} / \mathrm{H}_{2} \mathrm{O}_{2}\left(0.165\right.$ g.L $\mathrm{L}^{-1}, 4$ g.L $\mathrm{L}^{-1}$, pH 3), UV/TiO 2 (10 g.L $\left.\mathrm{L}^{-1} \mathrm{pH} 9\right)$.

\begin{tabular}{|l|c|c|c|c|c|c|c|}
\hline \multicolumn{1}{|c|}{ Process } & $\begin{array}{c}\text { Irradiation } \\
\text { time }(\mathrm{h})\end{array}$ & $\begin{array}{c}\text { Half } \\
\text { Life }^{*}(\mathrm{~h})\end{array}$ & $\begin{array}{c}\text { Max. } \\
\text { Removal }(\%)\end{array}$ & $\begin{array}{c}\mathrm{E}_{\mathrm{EO}} \\
\left(\mathrm{kWh} / \mathrm{m}^{3}\right)\end{array}$ & $\begin{array}{c}\text { Electricity } \\
\text { cost }\left(£ / \mathrm{m}^{3}\right)\end{array}$ & $\begin{array}{c}\text { Chemical } \\
\text { cost }\left(£ / \mathrm{m}^{3}\right)\end{array}$ & $\begin{array}{c}\text { Total cost } \\
\left(£ / \mathrm{m}^{3}\right)\end{array}$ \\
\hline 1. $\mathrm{UV} / \mathrm{TiO}_{2}$ (reactor) & 0.33 & 0.14 & 82 & 1500 & 60 & 0 & 60 \\
\hline 2. $\mathrm{UV} / \mathrm{Fe}^{2+} / \mathrm{H}_{2} \mathrm{O}_{2}$ & 3 & 1.1 & 85 & 1814 & 73 & 3.2 & 76 \\
\hline 3. $\mathrm{UV} / \mathrm{H}_{2} \mathrm{O}_{2}$ & 5 & 2.1 & 89 & 2612 & 104 & 3.1 & 107 \\
\hline 4. $\mathrm{Bio}+\mathrm{UV} / \mathrm{H}_{2} \mathrm{O}_{2}$ & 3 & 1.6 & 91 & 2634 & 105 & 3.1 & 108 \\
\hline 5. $\mathrm{Bio}+\mathrm{UV} / \mathrm{Fe}^{2+} / \mathrm{H}_{2} \mathrm{O}_{2}$ & 3 & 1.9 & 92 & 3002 & 120 & 3.2 & 123 \\
\hline 6. $\mathrm{Bio}+\mathrm{UV} / \mathrm{TiO}_{2}$ & 5 & 5.7 & 90 & 9088 & 364 & 0 & 364 \\
\hline
\end{tabular}

Combined electricity and chemical costs of the different options ranged from $£ 60 . \mathrm{m}^{-3}$ to $£ 364 . \mathrm{m}^{-3}$ with the chemical costs making up a maximum of $4.7 \%$ of the combined costs. Photocatalysis clearly seems to be the best option under the conditions studied here (10 g. $\left.\mathrm{L}^{-1} \mathrm{TiO}_{2}, \mathrm{pH} 9\right)$. Comparison to the current disposal cost of $£ 20-40 . \mathrm{m}^{-3}$ (DTI, 2004) indicates that these processes are likely to become economically suitable only once the disposal cost raise as is expected with predicted levels estimated to potentially be as high as $£ 100 . \mathrm{m}^{-3}$ within the next $10-15$ years. Overall, direct treatment with AOPs appears more 
economically effective than utilising them as a polishing stage as equivalent UV doses achieve similar levels of treatment indicating that the utilisation of the $\mathrm{OH}$ radical is less effective when used in a polishing process. The electrical energy per order, defined as the kWh of electrical energy required to reduce the concentration of a pollutant by 1 order of magnitude (90\%) in $1 \mathrm{~m}^{3}$ of contaminated water, is the most common method used to compare electricity use of AOPs. As mentioned in Section 2.5, modified $\mathrm{E}_{\mathrm{EO}}$ was used where $<90 \%$ were achieved. Across the trials the $\mathrm{E}_{\mathrm{EO}}$ ranged from $1500 \mathrm{kWh} \cdot \mathrm{m}^{-3}$ for the photocatalysis to $2612 \mathrm{kWh} . \mathrm{m}^{-3}$ for $\mathrm{UV} / \mathrm{H}_{2} \mathrm{O}_{2}$ which compares to values between $344-2000$ $\mathrm{kWh} . \mathrm{m}^{-3}$ when treating $5 \times 10^{-4}$ mol.L $\mathrm{L}^{-1}$ of reactive azo dyes using the same three treatments [29]. Both studies indentified the photocatalysis as the most energy efficient and the $\mathrm{UV} / \mathrm{H}_{2} \mathrm{O}_{2}$ as the least efficient reflecting differences in light adsorption between $\mathrm{TiO}_{2}$ and $\mathrm{H}_{2} \mathrm{O}_{2}$ at the operating wavelengths of the UV lamps [29].

Previous scale up of UV systems has indicated a substantial economic saving through improved efficiency such that likely electricity costs associated with the UV will decrease by a factor of ten when applied at full scale. Whilst this makes the economics of the UV seem more favourable the total cost of using such systems would then need to include peripheral equipment such as membranes in the photocatalysis and sludge management and chemical handling in the cases of $\mathrm{UV} / \mathrm{H}_{2} \mathrm{O}_{2}$ and photoFentons. Overall, estimated operating costs are likely to be a factor of 2-4 times lower and when coupled to the general benefits of compact footprint and rapid start up without performance deterioration then AOPs appear to be a viable option of small scale decentralised treatment of industrial wastewaters such as spent MWFs.

\section{Conclusions}

The semi-synthetic spent MWF studied here was found to be biodegradable during Zahn-Wellens test. Further, the wastewater was found to be treatable by ${ }^{\circ} \mathrm{OH}$ radicals and high removals were achieved in $\mathrm{UV} / \mathrm{TiO}_{2}$ reactor and by $\mathrm{UV} / \mathrm{H}_{2} \mathrm{O}_{2}$ and photo-Fenton processes. The $\mathrm{UV} / \mathrm{TiO}_{2}$ reactor was also found to be the cheapest option and could offer a viable alternative especially for smaller businesses. Photo- 
Fenton was also found to improve the biodegradability of spent MWFs and all AOPs were found to degrade the recalcitrant COD. However to apply the combined treatment would not be economical. Where biological treatment is not an option, optimised $\mathrm{UV} / \mathrm{TiO}_{2}$ would be the best alternative. Future challenges for its implementation include a development of better systems with significantly lower energy requirements through better understanding of the mechanisms involved in the $\mathrm{UV} / \mathrm{TiO}_{2}$ process and the use of alternative UV sources such LEDs or solar.

\section{Acknowledgement}

The authors wish to thank the Department of Trade and Industry for funding this work under the MEMBOX project (TP/3/WMM//6/I/16947) and Cimcool Europe for providing the MWF ultrafiltration permeate. The MEMBOX project was co-funded by the Technology Strategy Board's Collaborative Research and Development programme. The Technology Strategy Board is an executive body established by the Government to drive innovation (For more information visit www.innovateuk.org).

\section{References}

1. N. Hilal, G. Busca, F. Talens-Alesson, B.P. Atkin, Treatment of waste coolants by coagulation and membrane filtration, Chemical Engineering and Processing 43(2004), pp. 811-821.

2. DTI, BIO-WISE: A guide to biological treatment for metalworking fluids disposal. DTI Project: DTI/BW/25/2000/12/2000/NP URN 00/904. Crown, UK, 2004.

3. A. Rabenstein, T. Koch, M. Remesch, E. Brinksmeier and J. Kuever, Microbial degradation of water miscible metal working fluids, International Biodeterioration and Biodegradation 63 (2009), pp. $1023-1029$.

4. J.M. Burke and W.A. Gaines, Waste treatment. In Metalworking Fluids, J.P. Byers (ed), $2^{\text {nd }}$ edition, CRC Press, US (2006), pp. 301-324. 
5. N. Hilal, G. Busca and M.D.Waller, Treatment of metalworking fluids: development of a bioconsortium for the treatment of nanofiltration permeate, Journal of Chemical Technology and Biotechnology 80 (2005), pp. 641-648.

6. J.E. Anderson, T.V. Lofton, B.R. Kim, S.A. Mueller, Membrane bioreactor treatment of a simulated metalworking wastewater containing ethylenediaminetetraacetic acid and dicyclohexylamine, Water Environment Research 81 (2009), pp. 357-364.

7. D. Cheng, D. Phipps and R.M. Alkhaddar, Thermophillic aerobic wastewater treatment of waste metalworking fluids, Water and Environment Journal 20 (2006), pp. 227-232.

8. I. Oller, S. Malato, J.A. Sánchez-Pérez, W Gernjak, M.I. Maldonado, L.A. Pérez-Estrada, C. Pulgarín, A combined solar photocatalytic-biological field system for the mineralisation of an industrial pollutant at pilot scale, Catalysis Today 122 (2007), pp. 150-159.

9. R. Jaina, S. Sikarwara, Semiconductor-mediated photocatalyzed degradation of erythrosine dye from wastewater using $\mathrm{TiO}_{2}$ catalyst, Environmental Technology 31 (2010), pp. 1403-1410.

10. N. Azbar, T. Yonar, K. Kestioglu, Comparison of various advanced oxidation processes and chemical treatment methods for COD and color removal from a polyester and acetate fiber dyeing effluent, Chemosphere 55 (2004), pp. 35-43.

11. M. Pidou, S.A. Parsons, G.,Raymond, P. Jeffrey, T. Stephenson, B. Jefferson, Fouling control of a membrane coupled photocatalytic process treating greywater, Water Research 43 (2009), pp. 3932-3939.

12. H.R. Pouretedal, H. Beigy, and M.H. Keshavarz, Bleaching of Congo red in the presence of ZnS nanoparticles, with dopant of $\mathrm{Co}^{2+}$ ion, as photocatalyst under UV and sunlight irradiations, Environmental Technology 31 (2010), pp. 1183-1190.

13. M. Lapertot, S. Ebrahimi, S. Dazio, A. Rubinelli, C. Pulgarin, Photo-Fenton and biological integrated process for degradation of a mixture of pesticides, Journal of Photochemistry and Photobiology A: Chemistry 186 (2007), pp. 34-40. 
14. Z.X. Li and Y.G. Zhao, On-site treatment of dying wastewater by a bio-photoreactor system, Water Science and Technology 36 (1997), pp. 165-172.

15. OECD (1992) OECD guidelines for the testing of chemicals test no. 302B: Inherent Biodegradability: Zahn-Wellens/ EMPA Test.

16. Schuch, R., Gensicke, R., Merkel, K., Winter, J., 2000. Nitrogen and DOC removal from wastewater streams of the metal-working industry. Water Res. 34, 295-303.

17. C. von Sonntag and H.P. Schuchmann, $U V$ disinfection of drinking water and by-product formation - some basic considerations. Journal of Water Supply Research and Technology - Aqua 41 (1992), pp. 67-74.

18. Standing Committee of Analysts, Methods for the Examination of Waters and Associated Materials, 5 day Biochemical Oxygen Demand (BOD 5 ). HMSO, London (1988).

19. J.R. Bolton, M.I. Stefan, Fundamental photochemical approach to the concepts of fluence (UV dose) and electrical energy efficiency in photochemical degradation reactions. Research on Chemical Intermediates 28 (2004), pp. 857-870.

20. E.J. Rosenfeldt, K.G. Linden, The $R_{\mathrm{OH}, \mathrm{UV}}$ concept to characterize and the model $\mathrm{UV} / \mathrm{H}_{2} \mathrm{O}_{2}$ process in natural waters, Environmental Science and Technology 41 (2007), pp. 2548-2553.

21. H. Fallmann, T. Krutzler, R. Bauer, S. Malato, J. Blanco, Applicability of the photo-Fenton method for treating water containing pesticides, Catalysis Today 54 (1999), pp. 309-319.

22. M.N. Chong, B. Jin, C.W.K. Chow, C. Saint, Recent developments in photocatalytic water treatment technology: A review, Water Research 44 (2010), pp. 2997-3027.

23. A. Fujishima, T.N. Rao, D.A. Tryk, Titanium dioxide photocatalysis, Journal of Photochemistry and Photobiology C: Photochemistry Reviews 1 (2000), pp. 1-21.

24. M. Muruganandham, M. Swaminathan, Advanced oxidative decolourisation of reactive yellow azo dye by $\mathrm{UV} / \mathrm{TiO} \mathrm{O}_{2}, \mathrm{UV} / \mathrm{H}_{2} \mathrm{O}_{2}, \mathrm{UV} / \mathrm{H}_{2} \mathrm{O}_{2} / \mathrm{Fe}^{2+}$ processes - a comparative study, Separation and Purification Technology 48 (2006), pp. 297 - 303. 
25. R. Miller and J. Anderson, Methods of reducing chemical oxygen demand of metalworking fluids after pre-treatment by membrane separation, SME Technical Paper MR93-156 (1993), pp. 1-16.

26. S.A.O. Galvão, A.L.N. Mota, D.N. Silva, J.E.F. Moraes, C.A.O. Nascimento, O. Chiavone-Filho, Application of the photo-Fenton process to the treatment of wastewaters contaminated with diesel, Science of the Total Environment 367 (2006), pp. 42-49.

27. P.M. Nagarnaik, B. Boulanger, Advanced oxidation of alkylphenol ethoxylates in aqueous systems, Chemosphere (2011), doi:10.1016/j.chemoasphere.2011.06.105.

28. M. Muruganandham, M. Swaminathan, Photochemical oxidation of reactive azo dye with UV$\mathrm{H}_{2} \mathrm{O}_{2}$ process, Dyes and Pigments 62 (2004), pp. 269-275.

29. C. Fotiadis, N.P. Xekoukoulotakis, D. Mantzavinos, Photocatalytic treatment of wastewater from cottonseed processing: effect of operating conditions, aerobic biodegradability and ecotoxicity, Catalysis Today 124 (2007), pp. 247-253.

30. M. Muruganandham, K. Selvam, M. Swaminathan, A comparative study of quantum yield and electrical energy per order $\left(E_{E o}\right)$ for advanced oxidative decolourisation of reactive azo dyes by UV light, Journal of Hazardous Materials 144 (2007), pp. 316-322. 